\title{
PREFERENSI LEARNING MANAGEMENT SYSTEM DI MASA PANDEMI COVID
}

\author{
Andi Hildayanti' ${ }^{1}$ M Sya'rani Machrizzandi² \\ ${ }^{1}$ Jurusan Teknik Arsitektur, Universitas Islam Negeri Alauddin Makassar, Indonesia \\ ${ }^{2}$ Jurusan Teknik Informatika, Universitas Islam Negeri Alauddin Makassar, Indonesia \\ ${ }^{1}$ andi.hildayanti@uin-alauddin.ac.id, ${ }^{2}$ sya'rani.machrizzandi@uin-alauddin.ac.id
}

\begin{abstract}
ABSTRAK
Penelitian ini bertujuan untuk mengkomparasikan Learning Management System yang digunakan selama masa pandemi Corona Virus Disease atau lebih dikenal dengan istilah CoViD-19 di lingkup perguruan tinggi. Hasil komparasi tersebut akan menunjukkan keunggulan dan kelemahan Learning Management System yang ada sehingga memudahkan dosen untuk memilih aplikasi Learning Management System yang dianggap sesuai dengan kebutuhan perkuliahan. Selain itu, hasil komparasi ini juga menjadi dasar perumusan skala prioritas aplikasi Learning Management System di lingkup perguruan tinggi, tidak terkecuali di Universitas Islam Negeri Alauddin Makassar. Informasi Learning Management System yang digunakan tersebut dikumpulkan melalui pembagian kuesioner online agar memudahkan dalam proses analisis statistik. Dari hasil analisis tersebut diketahui bahwa aplikasi Learning Management System yang dominan digunakan adalah Google Classroom karena banyaknya aplikasi penunjang yang dengan mudah disinkronkan dalam satu akun pengguna, serta beban kuota internet yang lebih murah menjadi alasan kuat pemilihan media pembelajaran daring dari aplikasi google ini.
\end{abstract}

Kata Kunci-Media pembelajaran online, Pandemi, Google, komparasi, preferensi, daring.

\begin{abstract}
Aims of this research was to compare the Learning Management System used during the CoViD-19 pandemic in universities. The results of this comparison will show the advantages and disadvantages of the Learning Management System which making it easier for lecturers to choose the Learning Management System applications that are deemed appropriate to lecture needs. In addition, the results are also for formulating the priority scale of Learning Management System applications in the scope of higher education, including Alauddin State Islamic University Makassar. Information about Learning Management System applications used was collected through the distribution of online questionnaires to facilitate the statistical analysis process. From the analysis results, it is known that Learning Management System applications more widely used is Google Classroom because of the large number of supporting applications within easily synchronized in one user account, and the load of cheaper internet quota is a strong reason for choosing Learning Management System applications from Google.
\end{abstract}

Keywords_-Online learning media, pandemic, Google, comparison, preferences, online. 


\section{PENDAHULUAN}

Sejak diumumkannya kasus pertama COVID-19 di Indonesia pada 2 Maret 2020 lalu, jumlah kasus positif corona terus bertambah setiap harinya. Hingga akhirnya pemerintah mengimbau masyarakat untuk melakukan social distancing atau pembatasan sosial. Semua kegiatan yang melibatkan kerumunan orang banyak dihentikan sementara untuk meminimalkan potensi penyebaran virus yang cukup mematikan tersebut. Hal ini juga berdampak pada sektor Pendidikan, dimana kegiatan belajar dan perkuliahan di sekolah dan perguruan tinggi harus dihentikan sementara. Di masa pandemi ini, pembelajaran jarak jauh (distance learning) menjadi solusi alternatif. Semua mata pelajaran disampaikan pada peserta didik dengan menggunakan bantuan teknologi.

Sejak tahun 2014 Direktorat Pembelajaran dan Kemahasiswaan, Direktorat Jenderal Pendidikan Tinggi mengembangkan program Pembelajaran Daring Indonesia Terbuka dan Terpadu (PDITT), yang diluncurkan tanggal 15 Oktober 2014 oleh Wakil Presiden Boediono. 18 September 2016, berganti nama menjadi Sistem Pembelajaran Daring (SPADA).[1]

Program SPADA Indonesia pada dasarnya adalah implementasi dari Undang-Undang Republik Indonesia Nomor 20 Tahun 2003 tentang Sistem Pendidikan Nasional, UU No. 12 Tahun 2012 tentang Pendidikan Tinggi, dan Peraturan Menteri Pendidikan dan Kebudayaan Nomor 109 Tahun 2013 tentang Penyelenggaraan Pendidikan Jarak Jauh pada Pendidikan Tinggi. Dimana dalam Permendikbud 109 tahun 2013, menyatakan bahwa slah satu lingkup pendidikan jarak jauh yaitu lingkup mata kuliah. Salah satu tujuan program SPADA Indonesia untuk meningkatkan pemerataan akses terhadap pembelajaran yang bermutu di Perguruan Tinggi. Dengan sistem pembelajaran daring, SPADA Indonesia memberikan peluang bagi mahasiswa dari satu perguruan tinggi tertentu untuk dapat mengikuti suatu mata kuliah bermutu tertentu dari perguruan tinggi lain dan hasil belajarnya dapat diakui sama oleh perguruan tinggi dimana mahasiswa tersebut terdaftar [1][2].

Sistem pembelajaran daring (dalam jaringan) merupakan sistem pembelajaran tanpa tatap muka secara langsung antara pengajar dan peserta didik tetapi dilakukan melalui online yang menggunakan jaringan internet. Dalam penelitian ini, dosen harus memastikan kegiatan belajar mengajar tetap berjalan, meskipun siswa berada di rumah. Sehingga dosen dituntut dapat mendesain media pembelajaran sebagai inovasi dengan memanfaatkan media daring (online).

Sistem pembelajaran semacam ini dilaksanakan melalui perangkat personal computer (PC) atau laptop yang terhubung dengan koneksi jaringan internet. Dosen dapat melakukan pembelajaran bersama diwaktu yang sama menggunakan grup di media sosial seperti WhatsApp (WA), telegram, instagram, aplikasi zoom ataupun media lainnya sebagai media pembelajaran. Dengan demikian, dosen dapat memastikan peserta didik mengikuti pembelajaran dalam waktu yang bersamaan, meskipun di tempat yang berbeda.

Pembelajaran daring yang secara serentak dilakukan di sector Pendidikan mengalami berbagai kendala.
Permasalahan yang terjadi bukan hanya terdapat pada sistem media pembelajaran akan tetapi ketersediaan kuota yang membutuhkan biaya cukup tinggi harganya bagi peserta didik dan dosen guna memfasilitasi kebutuhan pembelajaran daring. Kuota yang dibeli untuk kebutuhan internet menjadi melonjak dan banyak diantara orangtua peserta didik yang tidak siap untuk menambah anggaran dalam menyediakan jaringan internet.

Hal ini pun menjadi permasalahan yang sangat penting bagi peserta didik, jam berapa mereka harus belajar dan bagaimana data (kuota) yang mereka miliki, sedangkan orangtua mereka yang berpenghasilan rendah atau dari kalangan menengah kebawah (kurang mampu). Hingga akhirnya hal seperti ini dibebankan kepada orangtua yang ingin anaknya tetap mengikuti pembelajaran daring.

Pembelajaran daring tidak bisa lepas dari jaringan internet. Jaringan internet merupakan aspek vital dalam mewujudkan interaksi individu [3][4]. Koneksi jaringan internet menjadi salah satu kendala yang dihadapi siswa yang tempat tinggalnya sulit untuk mengakses internet, apalagi siswa tersebut tempat tinggalnya di daerah pedesaan, terpencil dan tertinggal. Kalaupun ada yang menggunakan jaringan seluler terkadang jaringan yang tidak stabil, karena letak geografis yang masih jauh dari jangkauan sinyal seluler. Hal ini juga menjadi permasalahan yang banyak terjadi pada siswa yang mengikuti pembelajaran daring sehingga kurang optimal pelaksanaannya. Sehingga banyak perusahaan IT yang melakukan formulasi media pembelajaran online yang berupaya mengatasi permasalahan dalam proses pembelajaran daring. Dari berbagai media pembelajaran tersebut memiliki keunggulan dan kelemahan tersendiri yang mengharuskan pengguna untuk cerdas memilih yang sesuai dengan kebutuhan dan kendala yang dimilikinya.

Oleh karena itu, penelitian ini bertujuan untuk mengkomparasikan beberapa aplikasi Learning Management System yang digunakan selama pembelajaran daring di masa pandemi covid-19 lingkup perguruan tinggi, yang dalam penelitian ini adalah Universitas Islam Negeri Alauddin Makassar. Dengan menunjukkan keunggulan dan kelemahan masing-masing aplikasi Learning Management System yang ada sehingga memudahkan dosen untuk memilih aplikasi LMS pembelajaran daring yang dianggap sesuai dengan kebutuhan perkuliahan dan kondisi peserta didik selama proses perkuliahan daring.

\section{TINJAUAN PUSTAKA}

\subsection{Teknologi Pendidikan}

Teknologi Pendidikan sekarang sangat jauh berkembang. Dengan perkembangan teknologi yang sangat pesat membuat proses pembelajaran lebih cepat dan efektif. Perkembangan teknologi telah membawa banyak perubahan bagi dunia Pendidikan khususnya dengan menggunakan layanan internet.

Teknologi pendidikan didefinisikan sebagai suatu cara yang sistematis dalam mendesain, melaksanakan, dan mengevaluasi proses keseluruhan dari belajar dan 
pembelajaran dalam bentuk tujuan pembelajaran yang spesifik, berdasarkan penelitian dalam teori belajar dan komunikasi pada manusia dan menggunakan kombinasi sumber-sumber belajar dari manusia maupun non-manusia untuk membuat pembelajaran lebih efektif. Dengan demikian, sejak tahun 1970an, sudah ada pandangan bahwa manusia (dalam hal ini dosen) bukanlah satu-satunya sumber belajar.

Teknologi pendidikan merupakan penelitian dan aplikasi ilmu perilaku dan teori belajar dengan menggunakan pendekatan sistem untuk melakukan analisis, desain, pengembangan, implementasi, evaluasi dan pengelolaan penggunaan teknologi untuk membantu memecahkan masalah belajar dan kinerja. Tujuan utamanya adalah pemanfaatan teknologi untuk membantu memecahkan masalah belajar dan kinerja manusia.

Disisi lain. teknologi merupakan obyek formal bagaimana memfasilitasi proses belajar. Dengan kata lain, teknologi pendidikan adalah studi dan praktek etis dalam upaya memfasilitasi pembelajaran dan meningkatkan kinerja dengan cara menciptakan, menggunakan atau memanfaatkan, dan mengelola proses dan sumber-sumber teknologi yang tepat. Dalam mewujudkan tujuan teknologi Pendidikan maka digunakan pendekatan sistemi yaitu pendekatan yang holistik/komprehensif, bukan pendekatan yang bersifat parsial.

Kawasan teknologi pendidikan dapat meliputi kegiatan yang berkaitan dengan analisis, desain, pengembangan, pemanfaatan, pengelolaan, implementasi dan evaluasi baik proses-proses maupun sumber-sumber belajar. Dalam hal ini yang dimaksud dengan teknologi disini adalah teknologi dalam arti yang luas, bukan hanya teknologi fisik (hardtech), tapi juga teknologi lunak (softtech).[5]

Institusi pendidikan memerlukan upaya untuk mengkonstruksi pembelajaran dengan berbagai pendekatan sistem. Kecerdasan humanistik merupakan kunci utama pembelajaran yang memungkinkan seseorang mengkombinasikan teknologi berbagai sumber, media, bahan, metode belajar dapat secara signifikan meningkatkan pengalaman belajar pebelajar. Setiap pembelajaran diera normal baru membutuhkan konstruksi pembelajaran dengan memberikan otonomi ke pebelajar sehingga mewujudkan perilaku inkuiri. Desain pembelajaran yang masif dan terbuka pada era normal baru dalam Institusi pendidikan akan menghilangkan hambatan dalam menciptakan dan mempertahankan kecerdasan humanistik.[6]

\subsection{Metode pembelajaran daring}

Dalam rangka mencegah penyebaran dan penularan Covid-19 di lingkungan satuan pendidikan, Kemendikbud telah mengambil kebijakan untuk menutup perguruan tinggi di masa pandemi Covid-19. Selama masa penutupan, kegiatan belajar mengajar dialihkan melalui penyelenggaraan Belajar Dari Rumah dalam bentuk pembelajaran jarak jauh (PJJ) yang dibagi kedalam 2 (dua) pendekatan, yaitu :
1. pembelajaran jarak jauh dalam jaringan (daring)

2. pembelajaran jarak jauh luar jaringan (luring)

Di dalam pelaksanaan PJJ, satuan pendidikan dapat memilih pendekatan (daring atau luring atau kombinasi keduanya) sesuai dengan ketersediaan dan kesiapan sarana dan prasarana. Selain itu, waktu pembelajaran daring sepanjang hari menyesuaikan ketersediaan waktu, kondisi, dan kesepakatan peserta didik. Adapun proses pembelajaran daring terdiri atas :

1. Tatap Muka Virtual

Tatap muka virtual dapat dilakukan melalui video conference, teleconference, dan/atau diskusi dalam group di media sosial atau aplikasi pesan. Di dalam tatap muka virtual memastikan adanya interaksi secara langsung antara guru dengan peserta didik.

\section{Learning Management System (LMS)}

LMS merupakan sistem pengelolaan pembelajaran terintegrasi secara daring melalui aplikasi. Aktivitas pembelajaran dalam LMS, antara lain pendaftaran dan pengelolaan akun, penguasaan materi, penyelesaian tugas, pemantauan capaian hasil belajar, terlibat dalam forum diskusi, konsultasi dan ujian/penilaian. Contoh LMS, antara lain kelas maya rumah belajar, google classroom, ruang guru, zenius, edmodo, moodle, siajar LMS seamolec, dan lain sebagainya

Istilah pembelajaran daring dan luring muncul sebagai salah satu bentuk pola pembelajaran di era teknologi informasi seperti sekarang ini. Daring merupakan singkatan dari "dalam jaringan" sebagai pengganti kata online yang sering digunakan dalam kaitannya dengan teknologi internet. Daring adalah terjemahan dari istilah online yang bermakna tersambung ke dalam jaringan internet. Pembelajaran daring artinya adalah pembelajaran yang dilakukan secara online, menggunakan aplikasi pembelajaran maupun jejaring sosial.

Pembelajaran daring merupakan pembelajaran yang dilakukan tanpa melakukan tatap muka, tetapi melalui platform yang telah tersedia [7]. Segala bentuk materi pelajaran didistribusikan secara online, komunikasi juga dilakukan secara online, dan tes juga dilaksanakan secara online. Sistem pembelajaran melalui daring ini dibantu dengan beberapa aplikasi, seperti Google Classroom, Google Meet, Edmudo dan Zoom.

Sebuah kondisi dikatakan daring apabila memenuhi beberapa persyaratan sebagai berikut:

1) Di bawah pengendalian langsung dari alat yang lainnya.

2) Di bawah pengendalian langsung dari sebuah sistem.

3) Tersedia untuk penggunaan segera atau real time. 
4) Tersambung pada suatu sistem dalam pengoperasiannya,

5) Bersifat fungsional dan siap melayani

Selama pelaksanaan model daring, peserta didik memiliki keleluasaan waktu untuk belajar. Peserta didik dapat belajar kapan pun dan di mana pun, tanpa dibatasi oleh ruang dan waktu. Peserta didik juga dapat berinteraksi dengan guru pada waktu yang bersamaan, seperti menggunakan video call atau live chat. Pembelajaran daring dapat disediakan secara elektronik menggunakan forum atau message.

Belajar secara daring tentu memiliki tantangannya sendiri. Siswa tidak hanya membutuhkan suasana di rumah yang mendukung untuk belajar, tetapi juga koneksi internet yang memadai. Namun, proses pembelajaran yang efektif juga merupakan perihal penting yang harus tetap diperhatikan.

\section{METODE YANG DIUSULKAN}

Penelitian ini merupakan penelitian kuantitatif yang bertujuan menunjukkan gambaran preferensi aplikasi LMS melalui statistik deskriptif oleh pengguna media pembelajaran daring yaitu dosen dan mahasiswa di lingkup Universitas Islam Negeri Alauddin Makassar yang didasarkan pada fenomena dan realita yang terjadi selama proses penelitian. Data yang digunakan seluruhnya dikumpulkan dari berbagai sumber langsung maupun dari dokumen kebijakan dan data-data IT yang dibutuhkan, yang seluruhnya dikumpulkan melalui metode observasi, kuesioner, dan interview. Dari rekap data diketahui jumlah sampel penelitian sebanyak 148 responden yang terdiri dari 34 dosen dan 114 mahasiswa dari berbagai jurusan.

Data yang telah dikumpulkan dari berbagai sumber data kemudian di analisis menggunakan metode statistic deskriptif dan basic statistic dari software Ms. Excel. Luaran analisis menjadi dasar penentuan pilihan media pembelajaran dari yang dianggap prioritas dan unggul berdasarkan kriteria penilaian yang telah ditetapkan. Kriteria tersebut merupakan variable penelitian yang meliputi,

(1) Handal, dalam hal ini adalah kemudahan dalam mengakses dan menjalankan media/aplikasi

(2) Terpadu, dalam hal ini adalah memiliki banyak fitur pembelajaran

(3) Hemat, dalam hal ini adalah beban biaya kuota

(4) Keamanan, dalam hal ini adalah keamanan database media pembelajaran

\section{HASIL PENELITIAN}

Proses perkuliahan daring (dalam jaringan) sudah berjalan kurang lebih delapan bulan sejak imbauan untuk pembelajaran jarak jauh diberlakukan di UIN Alauddin Makassar. Sejauh penerapan perkuliahan daring digunakan sekurang-kurangnya dua LMS yaitu Google Classroom dan Lentera. Penggunaan LMS ini masih menggunakan aplikasi video conference sebagai penguat transfer materi pembelajaran seperti aplikasi Zoom Cloud Meeting dan Google Meet. Berdasarkan hasil survey yang diperoleh ternyata Google Classroom masih mendominasi sebagai media pembelajaran daring yang dikolaborasikan dengan aplikasi Zoom Cloud Meeting (lihat gambar 1, gambar 2, dan gambar 3).

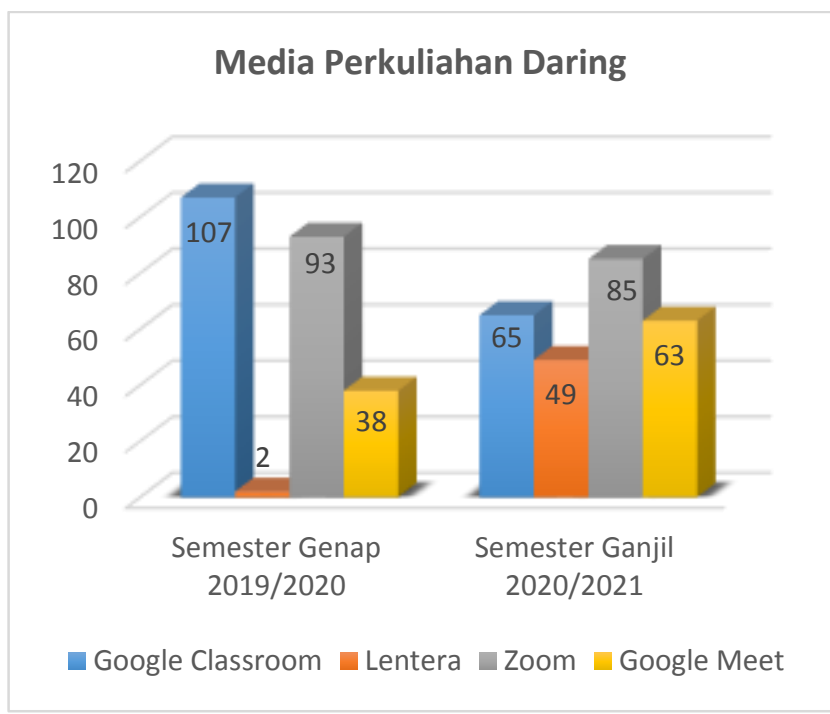

Gambar 1. Komparasi penggunaan media perkuliahan daring berdasarkan tanggapan responden

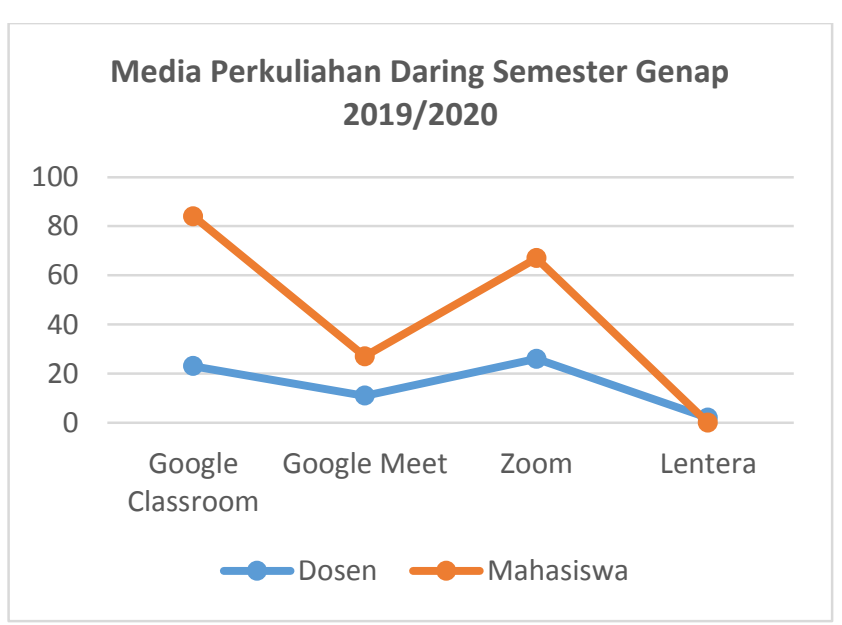

Gambar 2. Komparasi penggunaan media perkuliahan daring berdasarkan klasifikasi responden 


\section{Media Perkuliahan Daring Semester Ganjil 2020/2021}

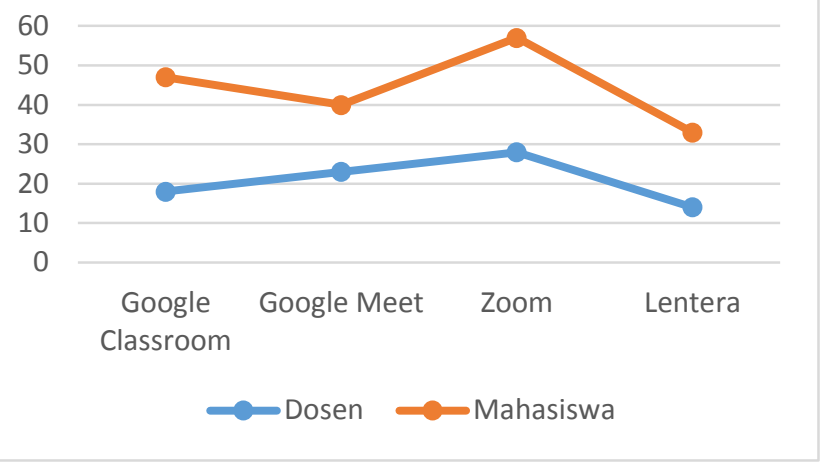

Gambar 3. Komparasi penggunaan media perkuliahan daring berdasarkan klasifikasi responden

Pemilihan ini didasarkan dari beberapa alasan seperti:

a. Penggunaan Google Classroom lebih mudah dan menghemat kuota selama penggunaanya

b. Penggunaan Zoom lebih mudah dan dapat direkam sebagai bukti pelaporan pelaksanaan perkuliahan

c. Google Classroom lebih banyak pilihan fitur pemberian materi, tugas, maupun kuis. Pengguna juga dapat mengunggah video ataupun link video dari YouTube.

d. Proses presentasi melalui Zoom lebih mudah ketika sharing screen dibandingkan aplikasi lainnya, meskipun membutuhan lebih banyak beban kuota.

Berdasarkan data yang diperoleh diketahui masih terdapat $26,5 \%$ dosen yang menggunakan sosial media sebagai media perkuliahan diawal pemberlakukan pembelajaran jarak jauh seperti aplikasi Whatsapp maupun Instagram. Namun, seiring berjalannya waktu mengalami peningkatan yang ditandai dengan jumlah dosen masih menggunakan sosial media Whatsapp hanya sebesar 5,8\%. Pada gambar 1 diketahui bahwa aplikasi Google Classroom merupakan LMS yang banyak digunakan selama dua semester.

Diawal masa pandemi, terhitung sekitar 73,5\% dosen menggunakan lebih dari satu aplikasi dalam pelaksanaan pembelajaran untuk memenuhi kebutuhan penyampaian materi kuliah secara maksimal. Namun, selebihnya sebanyak 26,5\% menggunakan aplikasi media sosial untuk distribusi materi kuliah dan pemberian intruksi tugas kuliah. Memasuki masa New Normal, pihak Universitas Islam Negeri Alauddin Makassar mulai melakukan sosialisasi Lentera yaitu aplikasi LMS yang dimiliki dan dikembangkan secara internal. Dan tercatat sekitar $42,9 \%$ dosen menggunakan aplikasi ini Lentera sebagai media perkuliahan daring.

Pemilihan aplikasi pembelajaran pada perkuliahan daring didasari atas beberapa pertimbangan keunggulan dan kelemahan dari aplikasi tersebut. Berikut ini adalah klasifikasi keunggulan dan kelemahan masing-masing media pembelajaran daring yang digunakan selama pembelajaran jarak jauh.

Tabel 1. Keunggulan Dan Kelemahan Media Pembelajaran Daring

\begin{tabular}{|c|c|c|}
\hline No. & Jenis Media & Kategori \\
\hline \multirow[t]{4}{*}{1} & \multirow[t]{4}{*}{ Google Meet } & Keunggulan \\
\hline & & 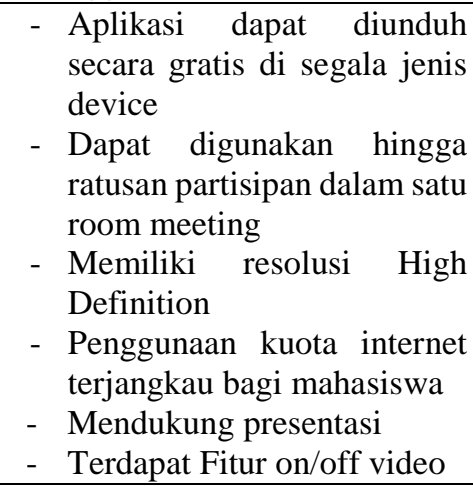 \\
\hline & & Kelemahan \\
\hline & & $\begin{array}{ll}\text { - } & \text { Membutuhkan jaringan } \\
\text { internet yang stabil } \\
\text { - } \\
\text { Tidak dapat merekam untuk } \\
\text { dokumentasi kegiatan } \\
\text { - } \begin{array}{l}\text { Fitur yang disediakan masih } \\
\text { standar }\end{array} \\
\end{array}$ \\
\hline \multirow[t]{4}{*}{2} & \multirow{4}{*}{$\begin{array}{l}\text { Google } \\
\text { Classroom }\end{array}$} & Keunggulan \\
\hline & & 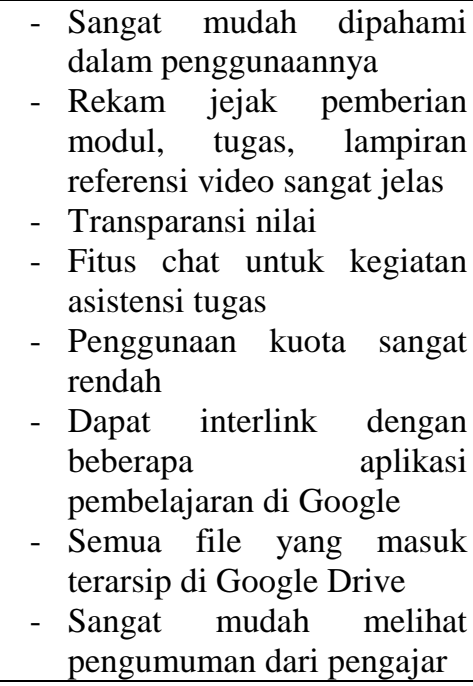 \\
\hline & & Kelemahan \\
\hline & & $\begin{array}{l}\text { - } \text { Tidak didukung video } \\
\text { conference (kecuali melalui } \\
\text { interlink dengan Google } \\
\text { Meet) } \\
\text { - Saat Google Drive Penuh } \\
\text { file tidak bisa dikirim } \\
\text { - Waktu pengiriman masih } \\
\text { bisa diatur }\end{array}$ \\
\hline \multirow[t]{2}{*}{3} & \multirow[t]{2}{*}{ Zoom } & Keunggulan \\
\hline & & $\begin{array}{l}\text { - } \text { Kapasitas ruang besar } \\
\text { - Kualitas video dan suara } \\
\text { terbaik }\end{array}$ \\
\hline
\end{tabular}


Universitas AL Asyariah Mandar

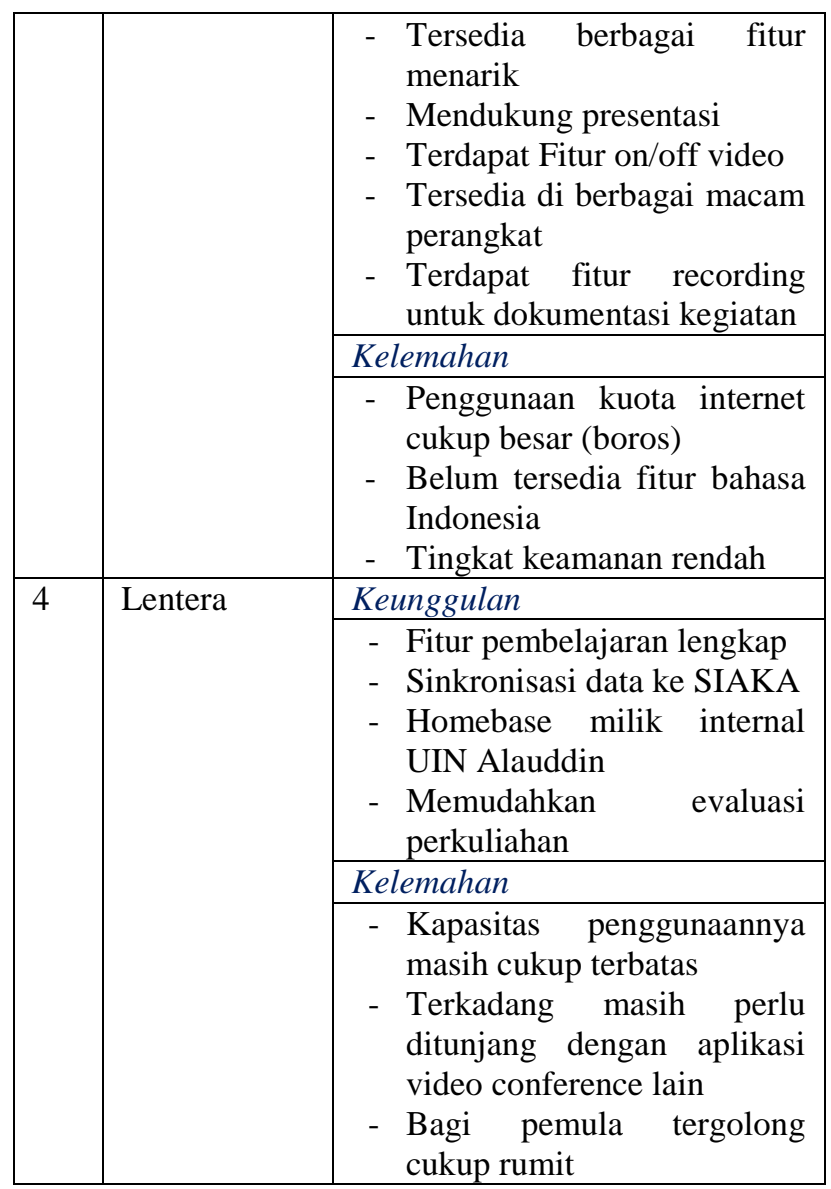

Berdasarkan klasifikasi pada tabel diatas, diketahui bahwa Google Classroom memiliki banyak keunggulan yang menjadi alasan utama banyaknya peminat atau pengguna aplikasi tersebut. Demikian pula dengan aplikasi Zoom. Meskipun lebih boros pada penggunaan kuota namun banyaknya fitur penunjang utamanya fitur recording menjadi alasan tersendiri bagi dosen dan mahasiswa tetap menggunakan aplikasi tersebut.

\section{KESIMPULAN}

Pemilihan aplikasi LMS dalam menunjang proses perkuliahan daring sangat bergantung pada kebutuhan pembelajaran yang akan diberikan dosen ke mahasiswa. Pemilihan aplikasi tersebut juga disesuaikan dengan substansi perkuliahan. Dominan untuk perkuliahan teori diberikan melalui aplikasi Google Classroom ataupun Lentera dengan mengupload modul dan video penjelasan yang memudahkan mahasiswa untuk memahami substasi materi. Sedangkan untuk matakuliah atau perkuliahan yang sifatnya praktikum sebagian besar dilakukan dengan menggunakan aplikasi video conference seperti Zoom, Google Meet, ataupun Big Blue Button Lentera.

\section{UCAPAN TERIMA KASIH}

Terima kasih kepada seluruh responden yaitu para dosen dan mahasiswa UIN Alauddin Makassar yang telah meluangkan waktunya untuk membantu memberikan gambaran terkait kondisi perkuliahan selama imbauan WFH (work from home).

\section{Daftar Pustaka}

Setiap sumber yang dikutip dalam tubuh artikel harusmuncul dalam referensi, dan semua sumber yang muncul dalam referensi harus dikutip dalam tubuh artikel. Daftar referensi harus disusun menurut abjad dan kronologis. Sumber yang dikutip adalah sumber utama yang mencakup setidaknya $80 \%$ dari yang diterbitkan dalam 10 tahun terakhir (kecuali bidang studi tertentu). Artikel ditulis dalam format IEEE. Penulis disarankan untuk menggunakan aplikasi manajemen referensi seperti Mendeley, EndNote, Zotero menggunakan Chicago Manual of Style edisi ke-16 dengan Times New Roman, ukuran font 12. Contoh:

[1] Anonim. 2020. Surat Edaran Sekretaris Jenderal Kementerian Pendidikan dan Kebudayaan Nomor 15 Tahun 2020 tentang Pedoman Penyelenggaraan Belajar dari Rumah dalam Masa Darurat Penyebaran Corona Virus Disease (Covid-19).

[2] Harnani, Sri. 2020. Efektivitas Pembelajaran Daring Di Masa Pandemi Covid-19. Webpage BDK Jakarta: Kementerian Agama RI.

[3] Hildayanti, A., \& Machrizzandi, M. S. R. (2020). The Application of IoT (Internet of Things) For Smart Housing Environments And Integrated Ecosystems. Nature: National Academic Journal of Architecture, 7(1), 80-88..

[4] Hildayanti, A., \& Machrizzandi, M. S. R. (2020). Sistem Rekayasa Internet Pada Implementasi Rumah Pintar Berbasis IoT. Jurnal Ilmiah Ilmu Komputer Fakultas Ilmu Komputer Universitas Al Asyariah Mandar, 6(1), 45-51.

[5] Gikas, J., \& Grant, M. M. (2013). Mobile computing devices in higher education: Student perspectives on learning with cellphones, smartphones \& social media. Internet and Higher Education. https://doi.org/10.1016/jjheduc.2013.06.002

[6] Curry, J. R. 2002. The Organizational Challege:IT and Revolution in Higher Education, Educause Review, Maret/April, 40-48

[7] Ermayulis, Syafni. 2020. Penerapan Sistem Pembelajaran Daring Dan Luring Di Tengah Pandemi Covid-19. Webpage STIT Al-Kifayah Riau. 